\title{
Local Perspective: Factors Associated with Covid-19 Preventive Behavior in West Nusa Tenggara, Indonesia
}

\author{
Artha Budi Susila Duarsa', Aena Mardiah'), \\ Fachrudi Hanafi',2), Dany Karmila' ${ }^{1}$, Ayu Anulus ${ }^{1)}$ \\ 1)Faculty of Medicine, Al-Azhar Islamic University, Mataram, West Nusa Tenggara \\ ${ }^{2)}$ Health Polytechnics of Ministry of Health, Mataram, West Nusa Tenggara
}

\section{ABSTRACT}

Background: The case fatality rate (CFR) of Covid-19 deaths in Indonesia on June 16, 2020 was $5.52 \%$ and $4.19 \%$ in West Nusa Tenggara. One of the causes of this high percentage of deaths is the lack of preventive behavior against Covid-19. This study aims to analyze factors associated with Covid-19 preventive behavior among people in West Nusa Tenggara, Indonesia.

Subjects and Method: A cross-sectional study was conducted in 10 cities/districts in West Nusa Tenggara from May-June 2020. A total of 385 people were enrolled in this study. Data were collected using a questionnaire distributed in the form of Google form and analyzed using multiple linear regressions with Stata 13.

Results: High education level ( $\geq$ high school) $(\mathrm{aOR}=0.43 ; 95 \% \mathrm{CI}=0.03$ to $0.82 ; \mathrm{p}=0.033$ ), perceived benefits $(\mathrm{aOR}=0.16 ; 95 \% \mathrm{CI}=0.07$ to $0.25 ; \mathrm{p}=0.001)$, and good knowledge $(\mathrm{aOR}=0.19$; $95 \% \mathrm{CI}=0.01$ to $0.37 ; \mathrm{p}=0.034)$ were increased the preventive behavior. While, male $(\mathrm{aOR}=0.54$; $95 \% \mathrm{CI}=-0.89$ to $-0.19 ; \mathrm{p}=0.002)$, perceived barriers $(\mathrm{aOR}=-0.16 ; 95 \% \mathrm{CI}=-0.25$ to $-0.07 ; \mathrm{p}=$ o.001) were decreased the preventive behavior toward Covid-19, and they were statistically significant.

Conclusion: Education higher than high school, high perceived benefit, and good knowledge are increase the local people behavior to prevent Covid-19 in West Nusa Tenggara.

Keywords: Covid-19, preventive behavior, West Nusa Tenggara

\section{Correspondence:}

Artha Budi Susila Duarsa. Faculty of Medicine, Universitas Islam Al-Azhar, Mataram. UnizarStreet Number 20, Turida, Sandubaya, Mataram, West Nusa Tenggara. Email: duarsaartha@unizar.ac.id. Mobile Phone: +62 812-9125-5000.

Cite this as:

Duarsa ABS, Mardiah A, Hanafi F, Karmila D, Anulus A (2020). Local Perspective: Factors Associated with Covid-19 Preventive Behavior in West Nusa Tenggara, Indonesia. J Health Promote Behav. 06(01): 1-8. https://doi.org/10.26911/thejhpb.2021.06.01.01.

cc (i) (2) Journal of Health Promotion and Behavioris licensed under a Creative Commons (c) $\mathrm{EY}$ NC SA Attribution-Non-Commercial-ShareAlike 4.0 International License.

\section{BACKGROUND}

A group of patients with an initial diagnosis of unknown pneumonia were admitted to the hospital by the end of December 2019. These patients are epidemiologically connected to the seafood and wet animal wholesale market in Wuhan, Hubei Province, China (Bogoch et al., 2020; Lu et al., 2020).

As of January 30 2020, 7734 cases were confirmed in China, and another 90 cases were also reported from several countries including Taiwan, Thailand, Vietnam, Malay- sia, Nepal, Sri Lanka, Cambodia, Japan, Singapore, United Arab Emirates, United States of America, Philippines, India, Australia, Canada, Finland, France, Germany and others. It was calculated that the case fatality rate (CFR) was $2.2 \%(170 / 7.824)$ (Bassetti et al., 2020). On June 16 2020, Covid-19 deaths in Indonesia were seen from the $5.52 \%$ CFR and $4.19 \%$ in West Nusa Tenggara Province (Diskominfotik NTB, 2020). 
The most Covid-19 cases in West Nusa Tenggara from March 16 to June 21, 2020, were on May 22, 2020 (54 cases), June 4, 2020 (52 cases), and May 26, 2020 (49 cases), respectively participate. The highest number of recoveries occurred on June 9, 2020 (77 cases recovered). The highest number of deaths occurred on June 3, June 10, and June 152020 (4 cases died) (Diskominfotik NTB, 2020).

Prevention and mitigation measures are critical applications in health and community services. The most effective preventive measures in society include: 1) Cleaning hands using a hand sanitizer if hands do not look dirty or washing hands with soap if hands look dirty; 2) Avoiding touching eyes, nose and mouth; 3) Apply the etiquette of coughing or sneezing by covering the nose and mouth with the inner arm or tissue, then throwing the tissue into the trash; 4) Wear a mask if you are in public places and crowds, and 5) Maintain a distance (at least 1 meter) from people experiencing respiratory symptoms. These preventive measures were adapted from previous outbreaks, including the 2003 SARS epidemic (Ministry of Health, 2020; WHO, 2010).

The best prevention is to avoid being exposed to the virus. Such practices proved effective in controlling the SARS epidemic in Hong Kong and continued to be practiced by the majority of society even after the SARS epidemic subsided in Hong Kong (Lau et al., 2010). This study aims to analyze the factors related to Covid-19 preventive behavior in West Nusa Tenggara Province, Indonesia.

\section{SUBJECTS AND METHOD}

\section{Study Design}

This was a cross-sectional study conducted in 10 cities/districts in West Nusa Tenggara in May-June 2020.

\section{Population and Sample}

The population in this study was the people of West Nusa Tenggara who were in the productive age range (15-64 years) and 385 people were randomly selected.

\section{Study Variables}

The dependent variable is Covid-19 prevention behavior. The independent variables include gender, age, education, income, availability of health facilities, policy exposure, perceived susceptibility, perceived seriousness, perceived benefits, perceived barriers, knowledge, and attitudes.

\section{Study Instruments}

The survey instrument was a questionnaire whose validity and reliability have been tested. This survey was made in Indonesian and distributed online, assisted by enumerators per district/city through communication WhatsApp application between researchers, enumerators, and study subjects.

\section{Data Analysis}

This study uses multivariate analysis to explain the effect of gender, age, education, income, availability of health facilities, exposure to regulation, perceived susceptibility, perceived seriousness, perceived benefits, perceived barriers, knowledge, and attitudes towards Covid-19 prevention behavior which were analyzed using a multiple linear regression. Univariate, bivariate, and multivariate analyzes used the Stata 13 program.

\section{Research Ethics}

The research ethics of this study included a submission sheet, anonymity, confidentiality, and ethical eligibility. Ethical feasibility in this study comes from the Ethics Committee of the Faculty of Medicine, Al-Azhar Islamic University with number: 18/EC/FK-06/ UNIZAR/V/2O2O.

\section{RESULTS}

This study was involved people in the West Nusa Tenggara, Indonesia. Sample characteristics were presented in Table 1. 
Table 1. Characteristics of study subjects

\begin{tabular}{|c|c|c|c|}
\hline Variables & Criteria & Frequency (n) & Percentage (\%) \\
\hline \multirow{2}{*}{ Age } & $<48$ years & 87 & 22.6 \\
\hline & $\geq 48$ years & 298 & 77.4 \\
\hline \multirow{2}{*}{ Gender } & Male & 210 & 54.55 \\
\hline & Female & 175 & 45.45 \\
\hline \multirow{2}{*}{ Education } & $<$ High School & 134 & 34.81 \\
\hline & $\geq$ High School & 251 & 65.19 \\
\hline \multirow{2}{*}{ Health Facility } & Not Available & 47 & 12.21 \\
\hline & Available & 338 & 87.79 \\
\hline \multirow{2}{*}{ Regulation } & Not Exposed & 64 & 16.62 \\
\hline & Exposed & 321 & 83.38 \\
\hline \multirow{2}{*}{ Perceived susceptibility } & Negative & 58 & 15.06 \\
\hline & Positive & 327 & 84.94 \\
\hline \multirow{2}{*}{ Perception of seriousness } & Negative & 31 & 8.05 \\
\hline & Positive & 354 & 91.95 \\
\hline \multirow{2}{*}{ Perceived benefits } & Negative & 27 & 7.01 \\
\hline & Positive & 258 & 92.99 \\
\hline \multirow{2}{*}{ Perceived barriers } & Negative & 42 & 10.91 \\
\hline & Positive & 343 & 89.09 \\
\hline \multirow{2}{*}{ Knowledge } & Good & 13 & 3.38 \\
\hline & Lack & 372 & 96.62 \\
\hline \multirow{2}{*}{ Attitude } & Negative & 26 & 6.75 \\
\hline & Positive & 359 & 93.25 \\
\hline \multirow{2}{*}{ Covid-19 Preventive Behavior } & Negative & 102 & 26.49 \\
\hline & Positive & 283 & 73.51 \\
\hline
\end{tabular}

Table 2. The relationship between attitude, knowledge, age, government regulation, health facilities, perceived susceptibility, perceived seriousness, perceived benefit, and perceived barrier to Covid-19 prevention behavior using Pearson correlation

\begin{tabular}{lcc}
\hline \multirow{1}{*}{ Independent Variables } & \multicolumn{2}{c}{ Covid-19 Preventive Behavior } \\
\cline { 2 - 3 } & $\mathbf{r}$ & $\mathbf{p}$ \\
\hline Attitude (positive) & 0.10 & 0.042 \\
Knowledge & 0.22 & $<0.001$ \\
Age (years) & 0.11 & 0.029 \\
Regulatory exposure (strong) & 0.10 & 0.041 \\
Availability of health facilities & 0.08 & 0.115 \\
Perception of susceptibility & 0.17 & 0.001 \\
Perception of seriousness & 0.19 & 0.001 \\
Perception of benefits & 0.25 & $<0.001$ \\
Perception of barriers & -0.08 & 0.108 \\
\hline
\end{tabular}

Table 3. The results of Chi-Square test on the relationship between sex, education, and income to the score of prevention behavior against Covid-19

\begin{tabular}{lcccc}
\hline \multicolumn{1}{c}{ Variable } & n & Mean & SD & p \\
\hline Gender & & & & \\
Female & 175 & 5.92 & 1.51 & 0.001 \\
Male & 210 & 5.29 & 1.99 & \\
$\begin{array}{l}\text { Education } \\
\text { <High School }\end{array}$ & & & & \\
$\begin{array}{l}\text { lHigh School } \\
\text { Income }\end{array}$ & 134 & 5.18 & 1.77 & 0.001 \\
<egional minimum wage & 251 & 5.79 & 1.81 & \\
$\geq$ Regional minimum wage & & & & \\
\hline
\end{tabular}


Table 3. Results of multiple linear regression analysis of the relationship between gender, age, education, regulatory exposure, perceived susceptibility, perceived seriousness, perceived benefits, perceived barriers, knowledge, attitudes, and income towards Covid-19 prevention behavior in West Nusa Tenggara

\begin{tabular}{lccc}
\hline \multicolumn{1}{c}{ Variable independent } & b & $\mathbf{9 5 \% C I}$ & p \\
\hline Gender (male) & -0.54 & -0.89 to -0.19 & 0.002 \\
Age (years) & 0.01 & -0.01 to 0.03 & 0.088 \\
Education ( $\geq$ High School) & 0.43 & 0.03 to 0.82 & 0.033 \\
Health facilities (available) & 0.01 & -0.13 to 0.14 & 0.961 \\
Regulation (exposed) & 0.04 & -0.20 to 0.29 & 0.729 \\
Perceived susceptibility (high) & 0.01 & -0.07 to 0.08 & 0.868 \\
Perceived seriousness (high) & 0.04 & -0.06 to 0.14 & 0.460 \\
Perceived benefits (high) & 0.16 & 0.07 to 0.25 & 0.001 \\
Perception of barriers(high) & -0.16 & -0.25 to -0.07 & 0.001 \\
Knowledge (high) & 0.19 & 0.01 to 0.37 & 0.034 \\
Attitude (positive) & 0.21 & -0.47 to 0.90 & 0.537 \\
Income ( $\geq$ Regional minimum wage) & -0.05 & -0.44 to 0.34 & 0.799 \\
N observes $=385$ & & & \\
Adjusted $\mathrm{R}^{2}=16.15 \%$ & & & \\
p $<0.001$ & & & \\
\hline
\end{tabular}

\section{DISCUSSION}

This study was conducted to find out how gender, age, education, income, availability of health facilities, policy exposure, perceived susceptibility, perceived seriousness, perceived benefits, perceived barriers, knowledge, and attitudes of the people of West Nusa Tenggara will help identify attributes that influence society in adopting healthy practices and preventive behaviors that are responsive to Covid-19.

The Covid-19 prevention behavior studied here is using masks, coughing and sneezing etiquette, washing hands, keeping a distance of at least one meter from other people, not leaving the house unless necessary, not touching the nose and face with hands, performing worship at home, washing hands with soap and water, and act actively in disseminating information regarding prevention against Covid-19 through social media. The results of the Hong Kong study also showed that more than $77 \%$ of participants reported good health performance for Covid19 (Kwok et al., 2020).
The results show that there was a relationship between gender and Covid-19 prevention behavior. Men were 0.54 times less likely to do Covid-19 prevention behavior than women. According to the report Global Health 2035, published in The Lancet in 2013, in developing countries by the United Nations, it is said that adult mortality fell faster among women than among men between 1992 and 2012 (Jamison et al., 2013).These deaths tend to result from low ability or behavior to prevent a problem or disease.

A study of knowledge, attitudes and practices (KAP) on Covid-19 among the Population in Saudi Arabia, conducted in 2017, showed that women had a greater level of knowledge about risk and prevention than men. Regarding precautionary measures, data show that men are significantly less likely than women to use safety and preventive measures 0.56 times (White et al., 2020).

This study shows that people with educational status is more than high school has the possibility of increasing Covid-19 prevention behavior 0.43 times compared to those 
with less education than high school. People with better education tend to know and learn about healthy behavior. Educated patients may be better able to understand their health needs, follow instructions, advocate for themselves and their families, and communicate effectively with health care providers. Education enhances skills such as literacy, develops effective habits, and can improve cognitive abilities. Skills acquired through education can affect health indirectly or directly, and they can affect a person's ability to navigate the health system, such as knowing how health plans are replaced (Goldman \& Smith, 2002).

This study shows that a high perceived benefit has the possibility of increasing Covid-19 prevention behavior 0.16 times compared to the perception of less benefit. People tend to be less willing to sacrifice for others, one of which is to prevent the spread of Covid-19 when the perception of benefits tends to be hostile or the benefits are uncertain (Gino et al., 2016).

The results of the analysis show that there was a relationship between perceived barriers and Covid-19 prevention behavior. Perceived high inhibition have the possibility of reducing Covid-19 prevention behavior 0.16 times compared to the perception of fewer barriers. Perceived barriers and fatalistic beliefs are also inversely related to the preventive behavior of Covid-19. Therefore, the level of adherence to preventive behavior increases by reducing perceived barriers. Excessive resistance can be a deterrent and prevent the creation of desired health behaviors. In this study, the participants had fewer perceived barriers to individual preventive behaviors, such as washing hands. Still, they were significantly affected by environmental barriers such as shortages of masks, alcohol pads, and disinfectants. A shortage of masks has been observed in most regions of the world due to the Covid-19 pandemic (Husnayain et al., 2020; Leung et al., 2020; Mahase, 2020).

This study shows that a high level of knowledge has the possibility of increasing Covid-19 prevention behavior 0.19 times compared to a low level of knowledge. Several studies conducted in other Asian countries have shown a high level of knowledge of Covid-19 among the general population and health workers (Huynh et al., 2020; Zhong et al., 2020). The differences in measurement and rating systems do not allow for an accurate comparison of knowledge levels across these studies.

Age, availability of health facilities, exposure to regulation statistically in this study were reported to be insignificant in their effect on the prevention of Covid-19 in the people of West Nusa Tenggara. The incidence of Covid-19 infection is seen most frequently in adult male patients with a mean patient age of between 34 and 59 years (Huang et al., 2020).

Health officials in Hong Kong have implemented multipurpose interventions to slow the spread of disease (Government of Hong Kong, 2020). The strategy also adopted by Indonesia includes screening health (measuring body temperature and a mandatory 14-day quarantine period for people arriving from outside the city), physical distancing (closing borders, reducing cross-border commuter services, delaying the resumption of classes at school, regulating homework for civil servants, and suspending public services), and extending enhanced laboratory surveillance programs to adult patients with fever and mild respiratory symptoms in emergency departments or general outpatient clinics in the public sector.

Perceived susceptibility, perceived seriousness, and attitudes, and income, were reported to be statistically insignificant in their influence on Covid-19 prevention behavior in the people of West Nusa Tenggara. 
Study by Bruine de Bruin \& Bennett (2020) found that the perception of the risk of Covid-19 infection on one of the preventive behaviors, namely hand washing, did not show a significant relationship. In the early stages of the COVID-19 epidemic, many people may be still hesitant to act on their risk perceptions and prefer to take an approach to wait and see. Study by Shahnazi et al. (2020) also found that the perception of susceptibility and the level of seriousness did not show a significant relationship in predicting preventive behavior from Covid-19.

This study generally has three limitations: first, data was collected via Google form (no face-to-face contact) assisted by one enumerator per 10 districts/cities due to specific conditions caused by limited mobility due to the Covid-19 pandemic; hence, it does not allow random sampling to select individuals. Second, some people, such as the elderly or low-income people tend not to have access to a smartphone. Third, the results of the questionnaire are based on selfreporting by study subjects who must consider the honesty in generalizing the data.

This study concluded that education, gender, perceived barriers, perceived benefits, and knowledge influence Covid-19 prevention behavior. This study can be used to prepare better governments to deal with future health crises involving infectious diseases, especially Covid-19. The results of this study are essential for informing future efforts that focus on the readiness of communities to comply with pandemic control measures.

\section{AUTHOR CONTRIBUTION}

Artha Budi Susila Duarsa designed, conceptualized, and wrote the study, Aena Mardiah collected and analyzed the data, Fachrudi Hanafi and Dany Karmila interpreted the results and constructed the discussion, and
Ayu Anulus analyzed the data and prepared the manuscript.

\section{CONFLICT OF INTEREST}

There was no conflict of interest of this study.

FUNDING AND SPONSORSHIP

This study was funded bythe Faculty of Medicine, Al-Azhar Islamic University, Mataram, West Nusa Tenggara.

\section{ACKNOWLEDGEIMENT}

The authors are grateful to the people in West Nusa Tenggara who have been helping and willing to join as the study subjects that took part in this study.

\section{REFERENCE}

Bassetti M, Vena A, Giacobbe DR (2020). The novel Chinese coronavirus (2019$\mathrm{nCoV}$ ) infections: Challenges for fighting the storm. European Journal of Clinical Investigation, 50(3): e13209. https://doi.org/10.1111/eci.13209.

Bogoch II, Watts A, Thomas-Bachli A, Huber C, Kraemer MUG, Khan K (2020). Pneumonia of unknown aetiology in Wuhan, China: potential for international spread via commercial air travel. J Travel Med. 27(2). https://doi.org/10.1093/jtm/taaaoo8

Bruine de Bruin W, Bennett D (2020). Relationships Between Initial COVID-19 Risk Perceptions and Protective Health Behaviors: A National Survey. Am J Prev Med. https://doi.org/10.1016/j.amepre.2020.05.001.

Diskominfotik NTB.(2020). COVID-19 NTB. Diskominfotik NTB. Retrieved from https://corona.ntbprov.go.id/

Gino F, Norton MI, Weber RA (2016). Motivated Bayesians: Feeling Moral While Acting Egoistically. Aeaweb Org. 30(3): 189-212. https://doi.org/10.1257/jep.30.3.189. 
Goldman DP, Smith JP (2002). Can patient self-management help explain the SES health gradient? Proceedings of the National Academy of Sciences of the United States of America, 99(16): 1092910934. https://doi.org/10.1073/pnas.162086599.

Government of Hong Kong. (2020). Hong Kong's multi-pronged response to COVID-19. Retrieved from https://www.hketojakarta.gov.hk/doc/pdf/Factsheet_coronavirus_Mar_17_E.pdf.

Huang C, Wang Y, Li X, Ren L, Zhao J, Hu Y, Zhang L, et al. (2020). Clinical features of patients infected with 2019 novel coronavirus in Wuhan, China. The Lancet, 395(10223): 497-506. https://doi.org/10.1016/So140-6736(20)30183-5.

Husnayain A, Fuad A, Su ECY (2020). Applications of Google Search Trends for risk communication in infectious disease management: A case study of the COVID-19 outbreak in Taiwan. International Journal of Infectious Diseases, 95: 221-223. https://doi.org/10.1016/j.ijid.2020.03.021.

Huynh G, Nguyen T, Tran V, Vo K, Vo V, Pham L (2020). Knowledge and attitude toward COVID-19 among healthcare workers at District 2 Hospital, Ho Chi Minh City. Asian Pacific Journal of Tropical Medicine, 13(6): 260-265. https://doi.org/10.4103/1995-7645.280396

Jamison DT, Summers LH, Alleyne G, Arrow KJ, Berkley S, Binagwaho A, Bustreo F, et al. (2013). Global health 2035: A world converging within a generation. https://doi.org/10.1016/So140-6736(13)62105-4.

Kwok KO, Li KK, Chan HHH, Yi YY, Tang A, Wei WI, Wong SYS (2020). Community Responses during Early Phase of Covid19 Epidemic, Hong Kong. Emerging Infectious Disease. 26(7): 1575-1579. https://doi.org/10.3201/eid2607.200500 .

Lau JTF, Griffiths S, Choi K, Lin C (2010). Prevalence of preventive behaviors and associated factors during early phase of the H1N1 influenza epidemic. American Journal of Infection Control, 38(5): 374-38o. https://doi.org/10.1016/j.ajic.2010.03.002.

Leung CC, Lam TH, Cheng KK. (2020). Mass masking in the COVID-19 epidemic: people need guidance. Lancet, 395(10228): 945. https://doi.org/10.1016/S0140-6736(20)30520-1

$\mathrm{Lu} \mathrm{H}$, Stratton CW, Tang YWW. (2020). Outbreak of pneumonia of unknown etiology in Wuhan, China: The mystery and the miracle. Journal of Medical Virology, 92(4): 401-402. https://doi.org/10.1002/jmv.25678

Mahase E. (2020). Novel coronavirus: Australian GPs raise concerns about shortage of face masks. BMJ (Clinical Research Ed.). https://doi.org/10.1136/bmj.m477.

Ministry of Health (2020). Pedoman kesiapan menghadapi COVID-19. Pedoman Kesiapan Menghadapi COVID-19: o115. Retrieved from https://corona.ntbprov.go.id/storage/dokumen/pedoman-covid-19.pdf

Shahnazi M, Ahmadi-Livani M, Pahlavanzadeh B, Rajabi A, Hamrah M, Charkazi A. (2020). Assessing Preventive Health Behaviors from COVID-19 Based on the Health Belief Model (HBM) among People in Golestan Province: A CrossSectional Study in Northern Iran. Research Square. https://doi.org/10.21203/RS.3.RS-24871/V1.

White MS, Omer DM, Mohammad DGN (2020). Knowledge, attitude and practice on prevention of airborne and droplet infections during the outbreak of Corona virus among the college 
Duarsa et al./ Local Perspective: Factors Associated with Covid-19 Preventive Behavior

students in University of Bisha, Saudi Arabia. International Journal of Contemporary Research and Review, 11 (04): 20773-20776. https://doi.org/10.15520/IJCRR.V11Io4.802.

WHO (2010). Chapter 5: SARS: lessons from a new disease. World Health Organization; World Health Organization. Retrieved from https://www.who.int/whr/2003/chapter5/en/index5.html.
Zhong BL, Luo W, Li HM, Zhang QQ, Liu XG, Li WT, Li Y (2020). Knowledge, attitudes, and practices towards Covid19 among Chinese residents during the rapid rise period of the Covid-19 outbreak: A quick online cross-sectional survey. International Journal of Biological Sciences, 16(10): 1745-1752. https://doi.org/10.7150/ijbs.45221. 